
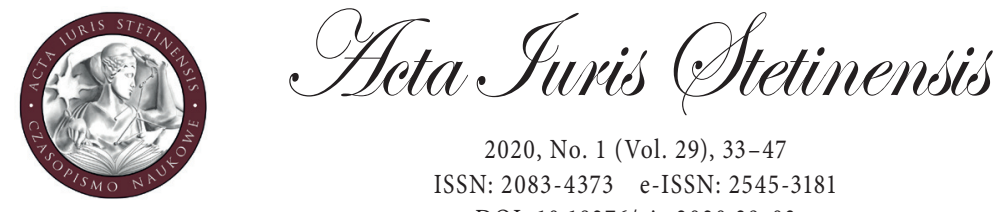

2020, No. 1 (Vol. 29), 33-47

ISSN: 2083-4373 e-ISSN: 2545-3181

DOI: $10.18276 /$ ais.2020.29-03

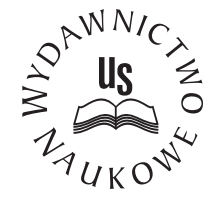

Aneta Kamińska-Nawrot

Ph. D.

Pomeranian University in Słupsk, Poland

Institute of Security and Management

e-mail: aneta.kaminska-nawrot@apsl.edu.pl

OPEN ACCESS

ORCID ID: 0000-0003-0270-2447

\title{
Body check or extrajudicial search - chaos in the Police Act
}

\begin{abstract}
A body check is a measure that is usually carried out in the event of a reasonable suspicion of a crime, i.e. when there are grounds to institute criminal proceedings. Moreover, the Police Act has never determined the limits of Police interference with the constitutional rights and freedoms of an individual, nor did it identify any adequate measures to protect the checked persons. These limits were determined by the provisions of the Regulation, ${ }^{1}$ according to which the Police could not uncover the parts of body covered with clothes.

The Constitutional Tribunal recognised these provisions as inconsistent with the Constitution of the Republic of Poland ${ }^{2}$ and ordered that the definition of a body check, determining the limits of Police interference with the rights and freedoms of an individual and authorising the person subject to a body check to appeal to the court against the decision of the Police, be included in the Police Act.
\end{abstract}

1 Regulation of the Council of Ministers of 29 September 2015 on the procedure for exercising certain competencies of Police officers, Dz.U. (Journal of Laws) 2015, item 1565.

2 Judgement of the Constitutional Tribunal of 14 December 2017, K 17/14, OTK ZU A/2018, item 4. 
The amendment to the Police Act and other acts, ${ }^{3}$ which implemented the judgment of the Constitutional Tribunal, authorised the person subject to a body check to have the actions of the Police verified by an independent court, but at the same time, it expanded the scope of Police interference with the rights and freedoms of an individual. The legislator of the Police Act and other acts did not remove the one prerequisite that simultaneously triggered a body check and the search of a person, but instead added other prerequisites that broadened the scope of Police measures in this respect. The limits of Police interference with the rights and freedoms of an individual were also expanded to include a check of the oral cavity, nose, ears and hair of the person subject to a body check and, in special cases, also their private body parts, which the Police officer may check visually or manually.

The purpose of this paper is to show that the provisions of the amended Police Act and other acts, to a large extent, failed to meet the provisions of the Judgment of the Constitutional Tribunal of 14 December 2017. Its extensive, non-transparent provisions broadened the authority of the Police to arbitrarily determine the limits of interference with the rights and freedoms of an individual, thereby eradicating them. The analysis of the amended Act and its implementing acts, as well as the statement of reasons for the draft Act, confirm the thesis that the amended provisions transformed a body check into an extrajudicial search.

Keywords: body check, search of a person, the Police Act, rights and freedoms of an individual, judgment of the Constitutional Tribunal

\section{Introduction}

A body check, the same as the search of a person, interferes with the constitutionally protected rights and freedoms of an individual and has triggered controversy for many years. It has been the object of numerous complaints addressed to the Ombudsman, who, on the basis of those complaints, submitted in 2014 a request to the Constitutional Tribunal ${ }^{4}$ to verify the constitutionality of the provisions authorising the performance of a body check, luggage and cargo check and search of a person and vehicles by such institutions as the Police, Border Guard, Customs Service, Internal Security Agency, Military Police, fiscal control, municipal guard or State Hunting Guard.

The Ombudsman's first objection, supported by the judgment of the Constitutional Tribunal, ${ }^{5}$ concerned the lack of a definition of a body check and search of

3 Act on amending the Police Act and certain other acts of 14 December 2018, Dz.U. (Journal of Laws) 2018, item 2399.

4 Ombudsman's petition no. II.519.344.2014.ST of 29 August 2014 to the CT; http://ipo.trybunal. gov.pl/ipo/Sprawa?\&pokaz=dokumenty\&sygnatura $=\mathrm{K} \% 2017 / 14$ (accessed 12.1.2018).

5 Judgement of the Constitutional Tribunal of 14 December 2017, op. cit. 
a person, as well as the limits of the interference of the above institutions with the rights and freedoms of an individual. The Ombudsman was very critical of the fact that the legislator failed to include any provisions that would justify limiting the integrity of the person and the right to privacy, and he left it to executive authorities to determine the extent to which the individual can enjoy their constitutional rights and freedoms. Moreover, he strongly emphasised the fact that those measures and the way they were conducted should be strictly and comprehensively governed by a legal act in the form of a statute, which was also emphasised in the judgment of the CT of 29 October 2013. " "(..) a body check (...) constitutes interference with the integrity of a person, protected pursuant to Article 41 section 1 of the Constitution, and the right to privacy, protected pursuant to Article 47 of the Constitution. In light of the requirements imposed on the legislator both by Article 31 section 1 and by Article 41 section 1 of the Constitution, in the event of interference with the two personal freedoms, only the legislator's intervention is admissible. The legislator must intervene in an exhaustive and exact manner. A legal instrument of a lower ranking than an act of law may only govern, subject to explicit authorisation granted by the legislator, practical issues associated with body check procedures."

The Ombudsman's second objection concerned the lack of provisions enabling the person subject to a body check to appeal against the decision of the institution conducting the body check to an independent court. The Ombudsman emphasised the fact that "(...) the legislator either did not provide for any appeal (including an appeal to the court), or he only provided for one possible appeal, namely an appeal to the prosecutor," by which he deprived any persons whose constitutional rights and freedoms were violated by public authorities of their right to trial.

Although the amended Act on the Police includes in its provisions (Article 15 section 5 and section 7), previously included in the Regulation, guarantees that the inspected person and the inspecting person are of the same sex, ensuring that the place is not accessible to bystanders and they have the right to have an additional person with them during such activities, it does not change the fact that this type of intervention should take place only and exclusively within the framework of conducting a criminal trial.

The Constitutional Tribunal agreed with the vast majority of the objections made by the Ombudsman, and on 14 December 2017, the CT concluded that Article $219 \S 2$ of the Code of Criminal Procedure ${ }^{7}$ and Article $44 \S 2$ of the Code of

6 Judgement of the Constitutional Tribunal of 29 October 2013, U 7/12, OTK 2013, No. 7/A, item 102.

7 Code of Criminal Procedure Act of 6 June 1997, consolidated text: Dz.U. (Journal of Laws) 2017, item 1904. 
Procedure for Cases of Petty Offences, ${ }^{8}$ to the extent that they provided for the search of a person without specifying the limits of that search, were not compliant with Articles 41 section 1 and 47 in association with Article 31 section 3 of the Constitution of the Republic of Poland. ${ }^{9}$ The Tribunal also determined that the provisions of the acts governing the activity of the Police, the Border Guard, the Municipal Guard, the Government Protection Bureau, the Military Police and Military Law Enforcement Units, the Internal Security Agency and Intelligence Agency, the Military Counterintelligence Service and Military Intelligence Service and the Central Anti-Corruption Bureau ${ }^{10}$, to the extent they authorised their respective officers to perform a body check without establishing the limits of that check, as well as provisions devoid of judicial review over a body check, were not compliant with Article 45 section 1 and Article 77 section 2 of the Constitution.

The provisions of implementing acts, with respect to performing a body check, were also considered to be non-compliant with Article 41 section 1 and Article 47 in association with Article 31 section 3 of the Constitution. ${ }^{11}$

8 Code of procedure for cases of petty offences Act of 24 August 2001, consolidated text: Dz.U. (Journal of Laws) 2016, item 1713, as amended.

9 Constitution of the Republic of Poland of 2 April 1997, Dz.U. (Journal of Laws) 1997, No. 78, item 483 , as amended.

10 Police Act of 6 April 1990, Dz.U. (Journal of Laws) 2017, item 2067 - art. 15 section 1 point 5 and art. 15 section 7; Border Guard Act of 12 October 1990, Dz.U. (Journal of Laws) 2016, item 1643, 1643, 1948 and 1955 and of 2017, item 60 - art. 11 section 1 point 2 and art. 11 section 1 point 2a.a; Municipal Guard Act of 29 August 1997, Dz.U. (Journal of Laws) 2016, item 706 and of 2017, item 60 - art. 12 section 1 point 3a and art. 20; Government Protection Bureau Act of 16 March 2001, Dz.U. (Journal of Laws) 2017, item 985 - art. 13 section 1 point 4; Military Police and Military Law Enforcement Units Act of 24 August 2001, Dz.U. (Journal of Laws) 2016, item 1483 and 1948 and of 2017, item 244, 768 and 1086 - art. 17 section 1 point 10 and art. 24 section 1; Internal Security Agency and Intelligence Agency Act of 24 May 2002, Dz.U. (Journal of Laws) 2017, item 1920 - art. 23 section 1 point 5 and art. 23 section 7 point 1; Military Counterintelligence Service and Military Intelligence Service Act of 9 June 2006, Dz.U. (Journal of Laws) 2017, item 1978 - art. 44 section 2 point 5; Central Anti-Corruption Bureau Act of 9 June 2006, Dz.U. (Journal of Laws) 2017, item 1993 - art. 14 section 1 point 5 and art. 14 section 7 point 1.

11 Regulation of the Minister of Home Affairs and Administration of 15 December 2006 on border control performed by Border Guard Officers, Dz.U. (Journal of Laws), No. 238, item 1729, of 2008, No. 223, item 1474 and of 2017, item $287-\$ 5$ section 1-4, 6 and 7; Regulation of the Council of Ministers of 18 December 2009 on the scope and means of certain measures performed by municipal (city) guard officers, Dz.U. (Journal of Laws), No. 220, item 1722 and of 2011, No. 222, item $1329-\$ 10$ section 1 point 2, $\$ 10$ section 3-6; Regulation of the Council of Ministers of 9 April 2002 on the specific procedures of the Government Protection Bureau Officers and the assistance of other institutions, Dz.U. (Journal of Laws), No. 57, item $519-\$ 9$ and $\$ 10$; Regulation of the Minister of National Defence of 14 December 2001 on specific procedures for exercising certain competencies of Military Police officers, Dz.U. (Journal of Laws), No. 157, item 1851 and of 2008, No. 182, item $1129-\$ 19-21$; Regulation of the Council of Ministers of 26 April 2005 on ordering 
The judgment of the CT was executed by the Act amending the Police Act and certain other acts of 14 December 2018. ${ }^{12}$ However, this Act not only amended the provisions questioned by the $\mathrm{CT}$, but it also introduced regulations that deviated from the constitutional standards much more than those that had been considered non-compliant with the provisions of the Constitution, making a body check an extrajudicial search of a person.

However, considering the fact that analysis of the regulations governing the issue of a body check by the respective institutions would significantly exceed the predetermined framework of the publication, these deliberations will focus on the right of the Police to perform a body check, as referred to in Article 15 section 1 point 5 of the Police Act of 6 April 1990, ${ }^{13}$ hereinafter referred to as the Police Act.

persons to behave in a specific way, asking for ID, detention, search, body check, luggage and cargo check and registering events by Internal Security Agency officers, Dz.U. (Journal of Laws), No. 86, item $733-\$ 29$ section 1-3; Regulation of the Council of Ministers of 25 July 2006 on ordering persons to behave in a specific way, asking for ID, detention, search, body check, luggage and cargo check and registering events by Central Anti-Corruption Bureau officers, Dz.U. (Journal of Laws), No. 142, item $1014-\$ 29$ section 1-3.

12 This Act amended the following legal instruments: Border Guard Act of 12 October 1990, Dz.U. (Journal of Laws) 2017, item 2365, as amended; Act on protecting the state borders of 12 October 1990, Dz.U. (Journal of Laws) 2018, item 1869; Code of Criminal Procedure Act of 6 June 1997, Dz.U. (Journal of Laws) 2017, item 2365; Municipal Guard Act of 29 August 1997, Dz.U. (Journal of Laws) 2016, item 706 and of 2018, item 60 - art. 12 section 1 point 3a and art. 928; Military Police and Military Law Enforcement Units Act of 24 August 2001, Dz.U. (Journal of Laws) 2018, item 430, 650, 1544; Internal Security Agency and Intelligence Agency Act of 24 May 2002, Dz.U. (Journal of Laws) 2018, item 2387 and 2245; Act on granting protection to foreign nationals on the territory of the Republic of Poland of 13 June 2003, Dz.U. (Journal of Laws) 2018, item 1109 and 1669; Military Counterintelligence Service and Military Intelligence Service Act of 9 June 2006, Dz.U. (Journal of Laws) 2017, item 1978 and of 2018, item 650, 1544 and 1669; Central Anti-Corruption Bureau Act of 9 June 2006, Dz.U. (Journal of Laws) 2018, item 2104; Prison Service Act of 9 April 2010, Dz.U. (Journal of Laws) 2018, item 1542, 1669 and 2245; Foreign Nationals Act of 12 December 2013, Dz.U. (Journal of Laws) 2018, item 2094; State Protection Service Act of 8 December 2017, Dz.U. (Journal of Laws) 2018, item 138, as amended; and Marshal's Guard Act 26 January 2018, Dz.U. (Journal of Laws), item 729 and 1669.

13 Police Act of 6 April 1990, consolidated text: Dz.U. (Journal of Laws) 2019, item 161, as amended. 


\section{A body check after execution of the judgment of the $\mathrm{CT}^{14}$}

Despite numerous objections of the Ombudsman, the Constitutional Tribunal, as well as legal academics, ${ }^{15}$ the legislator did not amend the uniform prerequisite for a body check and the search of a person, simultaneously triggering Police measures pursuant to the Police Act and the criminal procedure. Unfortunately, pursuant to the provisions of Article 15 section 1 point 5 of the Police Act, a body check is still performed if there is a reasonable suspicion of a criminal offence, which coincides with the moment that constitutes the basis to institute an investigation. ${ }^{16}$ Moreover, the catalogue of prerequisites to perform a body check was extended, further aggravating the problem. Currently, a body check may also be performed to find weapons or other hazardous items that can serve to commit a criminal offence or the possession of which is prohibited or items that can constitute evidence in a procedure conducted in association with the performance of Police tasks or in order to find items that are subject to confiscation in the event of reasonable suspicion that a person has weapons or such items or reasonable suspicion that they were used to commit a criminal offence.

Apart from the main prerequisite triggering a body check, the other prerequisites are, in fact, the purposes of a body check, which were previously included in the executive Regulation concerning the procedure for executing certain powers of Police officers, ${ }^{17}$ repealed as a result of execution of the judgment of the CT of 14 December 2017. The artificially identified purposes serving as additional grounds to perform a body check not only are not in any way justified, but they also cause chaos in legal regulations. The CT is of the opinion that regulations that directly affect the constitutional rights and freedoms of a person should be strictly compliant with the requirements concerning their clarity. ${ }^{18}$ Unfortunately, in this case, the amendments cause much chaos, not only for persons who may be subject to this procedure, but also for the institution that exercises this law. It

14 Judgement of the Constitutional Tribunal of 14 December 2017, op. cit.

15 Szumiło-Kulczycka, D., Kontrola osobista, przeglądanie zawartości bagaży, przeszukanie (przyczynek do kwestii racjonalności legislacji), "Państwo i Prawo" 2012, No. 3, p. 36 ff. Karaźniewicz, J., Przeszukanie i czynności zbliżone do przeszukania w teorii i praktyce organów ścigania, in: Hofmański, P. (ed.), Węzłowe problemy procesu karnego. Materialy konferencyjne - Kraków, 25-28.9.2008, Warszawa 2010, pp. 276-278; Kaznowski, A., Karnoprocesowe aspekty przeszukania osoby w polskiej procedurze karnej, "Wojskowy Przegląd Prawniczy" 2008, No. 3, pp. 71-72.

16 Cf.: Grochowski, J., Milicyjne przeszukanie pozaprocesowe a konstytucyjne prawa osobiste w PRL, "Problemy Prawa Karnego" 1989, No. 15, pp. 26-27; Karaźniewicz, J., op. cit., p. 280.

17 Regulation of the Council of Ministers of 29 September 2015, op. cit.

18 Judgement of the Constitutional Tribunal of 14 December 2017, op. cit. 
should be firmly emphasised that "the legislator cannot, by formulating ambiguous legal provisions, leave too much freedom to the institutions that are to apply those provisions in terms of limiting the constitutional rights and freedoms of an individual. Exceeding a certain level of ambiguity of legal provisions may be in itself a prerequisite to conclude that they are non-compliant with the principle of the rule of law." 19

However, the most worrying are the provisions of Article $15 \mathrm{~d}$ of the Police Act, ${ }^{20}$ which, determining the scope of actual body check measures, deeply interfere with the constitutional rights of an individual and obliterate the distinction between a body check and the search of a person.

Pursuant to the wording of Article $15 \mathrm{~d}$ section 1 of the Police Act, a body check involves checking the following:

1. Clothes, footwear and objects that a person is wearing on their body, without uncovering the parts of the body covered by clothes.

2. Luggage and other items that a person is carrying with them.

3. Clothes, footwear and objects that a person is wearing on their body, uncovering parts of the body covered by clothes insofar as may be necessary to remove weapons or items referred to in Article 15 section 1 point 5 in the event they were discovered during the check referred to in point 1 or 2 and if the measures referred to in points 1 and 2 are not sufficient to remove them.

4. The oral cavity, nose, ears and hair.

5. In duly justified cases, private body parts. ${ }^{21}$

Accordingly, the amended act ${ }^{22}$ expanded the scope of a body check to include checking the oral cavity, nose, ears and hair and, in duly justified cases, private body parts. Before the entry into force of the judgment of the $\mathrm{CT},{ }^{23}$ the repealed provisions of the Regulation concerning the procedure for executing certain powers of Police officers of $2015^{24}$ determined the line between the search of a person and a body check, namely the prohibition to uncover the body parts covered by clothes. Given the existing state of the law, this difference is only apparent. The solution provided for in Article 15 section 1 point 3 of the Police Act was justified in the following way: "To ensure compliance of the regulation with the principle of

19 Tuleja, P. (ed.), Konstytucja Rzeczypospolitej Polskiej. Komentarz, Warszawa 2019, p. 31.

20 Police Act of 6 April 1990, op. cit.

21 Art. 15d section 1 of the Police Act of 6 April 1990, op. cit.

22 Act on Amending the Police Act and certain other acts of 14 December 2018, op. cit.

23 Judgement of the Constitutional Tribunal of 14 December 2017, op. cit.

24 Regulation of the Council of Ministers on the procedure for exercising certain competencies of Police officers of 29 September 2015, op. cit. 
proportionality of the interference of a public authority with constitutionally protected rights and freedoms, the measure referred to in Article 15 section 1 point 3 (...) is subsidiary to the measures referred to in Article 15 section 1 point 1 and Article 15 section 1 point 2 and applies only if, in the course of those measures, weapons or other hazardous objects are discovered and if those measures are not sufficient to remove them." ${ }^{25}$ Unfortunately, nothing whatsoever is said about the reasons for introducing the provisions on checking the oral cavity, nose, ears, hair and, in duly justified cases, private body parts. Leaving this without a word of comment, despite such deep interference of public authorities, is astonishing, considering the fact that these kinds of measures were previously reserved only for law enforcement authorities searching a person in association with a criminal offence.

Concerning the principle of proportionality claimed in the statement of reasons by members of the committee proposing the draft act amending the Police Act, it should be noted, after L. Garlicki, that the principle of proportionality expresses the conviction that the intensity of interference with the legal situation of the individual must by justified by the rank of public interest that is thereby promoted ${ }^{26}$. Thus, this principle assumes weighing the interests leading to the choice of certain values, which means favouring some at the expense of others. ${ }^{27}$ These conditions must be satisfied both at the stage of law-making and applying the law to such sensitive measures as a body check or the search of a person.

The existing provisions of Article $15 \mathrm{~d}$ of the Police Act identify two situations. The first, discussed in Article 15d section 1 point 1 of the Police Act, concerns checking the clothes, footwear and items that a person is wearing on their body without uncovering the parts of the body covered by clothes. The other situation, discussed in Article 15d section 1 point 3 of the Police Act, takes place if, during the check without uncovering the parts of the body covered by clothes, weapons or other items referred to in Article 15 section 1 point 5 of the Police Act were discovered and, that check being insufficient, it was necessary to uncover the body. In this case, the purpose of the measure is to remove those items. The question is then: what is the purpose of a body check in the other cases referred to in Article $15 \mathrm{~d}$ section 1 point 1, 2, 4 and 5 of the Police Act? Undoubtedly, the purpose of a body check in every case is to find weapons or items referred in Article 15

25 Statement of reasons for the commission of the draft Act on amending the Police Act and certain other acts - print no. 3088 of 6.12 .2018 .

26 Garlicki, L., Przestanki ograniczania konstytucyjnych praw i wolności (na tle orzecznictwa Trybunału Konstytucyjnego), "Państwo i Prawo" 2001, vol. 10, p. 18.

27 Łabno, A., Istota zasady proporcjonalności, in: Dukiet-Nagórska, T. (ed.), Zasada proporcjonalności w prawie karnym, Warszawa 2010, p. 22. 
section 1 point 5 of the Police Act, which makes the provision incomprehensible and groundless.

Another curious provision is Article $15 \mathrm{~d}$ section 2 of the Police Act. According to this provision, "(...) during the check referred to in paragraph 1.3 and 1.5 , the person who is being checked should be partly dressed (...)." In this case, it cannot be disregarded that the legislator transferred elements of the tactics of the search of a person to the tactics of a body check. By quoting the clause of minimising interference with the personal rights of the checked person and of using interference measures adequate to the circumstances in the statement of reasons for the act, the legislator noted that it was the duty of a Police officer to allow a person to put on an item of clothing already checked before checking another item. ${ }^{28}$ Of course, in the case of the search of a person, this is appropriate and desired, because it involves removing clothes from a person rather than uncovering the parts of the body covered by clothes. However, in association with the provisions governing a body check, such provisions should be criticised. It is hard to identify the concept of "uncovering the parts of the body covered by clothes" referred to in Article 15d section 1 point 1 and 3 of the Police Act with the "undressing of a person" referred to in Article 15d section 2 of the Police Act. So far, in practice, the prohibition "to uncover the parts of the body covered by clothes" meant so-called palpation without removing the last layer of clothes covering the body, whereas uncovering meant pulling up a top or trouser leg without taking them off, i.e. without undressing a person. Meanwhile, undressing was solely linked with the search of a person in association with a criminal offence, and this involved removing the clothes a person was wearing. Accordingly, such formulation of the provisions not only exposes the legislator to the accusation of inconsistency, but also puts into question the validity of the existence of a body check alongside the search of a person.

Another change that obliterates the difference between a body check and the search of a person is contained in Article 15d section 3 of the Police Act. According to this provision, the oral cavity, nose, ears and hair and, in duly justified cases, private body parts may be checked visually or manually. It should be noted here that the legislator, who, given the degree of interference with the rights and freedoms of an individual, should be expected to be particularly precise, did not make any effort to explain what "duly justified cases" meant. By this, the legislator allowed a visual or manual check of the oral cavity, nose, ears, hair and the private parts of a person to be performed both if the items referred to in Article 15 section 1 point 5 of the 
Police Act are discovered during a body check and if no such items are discovered, regardless of the result of the search, and he left it to the discretion of the Police officer to decide whether a given case is duly justified. According to the CT, correct legislation means that legal provisions are formulated in a precise, correct and clear manner, especially if they concern the rights and freedoms of an individual. ${ }^{29}$ "The requirement of clarity means that legal provisions should be clear and understandable for their addressees, who expect a rational legislator to establish regulations that do not raise any doubts as to the wording of the obligations imposed on them and the rights granted to them." 30 "An unclear and imprecise provision makes its addressees uncertain about the scope of their rights and obligations, and it gives too much freedom to the institutions that apply that provision and enables them, instead of the legislator, to decide on issues that the legislator failed to govern in a clear and precise manner." ${ }^{\prime 1}$

Even though the provision deeply interferes with the constitutional rights and freedoms of an individual, the legislator did not specify the procedure of a manual private body parts check. The provision is limited to one sentence, according to which the person authorised to perform the check is a Police officer and that the Police officer may request the checked person to take a body position that will enable the checking of their private body parts.

Before the changes introduced in the execution of the judgment of the $\mathrm{CT}^{32}$ in our legal system based on the principles of a democratic rule of law, private body parts could be checked solely in the procedure of the search of a person in association with a criminal offence. Another precaution was that this measure could be conducted by an authorised person, namely a physician or authorised health worker, and never by a Police officer. Obviously, a visual check could always take place, and this visual method never raised any objections. However, a manual check was always subject to penal procedure regulations, which were exceptionally restrictive. Unfortunately, the provisions of the amended Police Act make it possible to substitute not only the legislator but also a physician or qualified health worker with a Police officer.

29 Cf. Judgement of the Constitutional Tribunal of 11 January 2000, K 7/99, OTK ZU 1/2000, item 2; Judgement of the Constitutional Tribunal of 21 March 2001, K 24/00, OTK ZU 3/2001, item 51. Judgement of the Constitutional Tribunal of 10 December 2002, K 6/02, OTK ZU 7A/2002, item 91; Judgement of the Constitutional Tribunal of 14 December 2017, op. cit.

30 Judgement of the Constitutional Tribunal of 21 March 2001, op. cit.

31 Tuleja, P., op. cit., p. 31.

32 Judgement of the Constitutional Tribunal of 14 December 2017, op. cit. 
The structure of the provisions of Article $15 \mathrm{~d}$ section 1 point 3 of the Police Act is also surprising, since, although it enables uncovering the body parts covered by clothes, it does not provide for checking private body parts, which is instead governed separately by point 5 . Moreover, the statement of reasons for the draft act concerning this part of the provision entirely disregards the issue of checking private body parts: "The scope of procedures covered by a body check was extended to include checking the oral cavity, nose, ears and hair of the checked person and, in duly justified cases, also checking other body parts, including the parts covered by clothes." ${ }^{33}$ It should be noted here, by way of comparison, that the statement of reasons for the provisions of the Border Guard Act ${ }^{34}$ has two pages of commentary on checking private body parts, and even though it may seem controversial, the arguments of international security related to aviation law and European civil aviation security regulations may have some supporters. ${ }^{35}$ Unfortunately, no arguments are provided concerning the corresponding provisions of the Police Act, which suggests that none exist.

In a democratic State governed by the rule of law, an important principle is civic trust in the State and the laws made by the State, as well as the principle of social justice. ${ }^{36}$ The former is a guarantee of the decency of legislation ${ }^{37}$ and the principle of proportionality, ${ }^{38}$ and the latter is supposed to ensure balance in social relations and prevent certain groups from acquiring unjust privileges not supported by objective criteria or requirements. ${ }^{39}$ The principle of proportionality guarantees that any limitations imposed by the legislator are proportional to the potential threats and are not arbitrary and that the application of proportionality in actual procedures is effectively monitored. In the event of a conflict between the constitu-

33 Statement of reasons, op. cit.

34 Art. 2 point 1 of the Act on Amending the Police Act and certain other acts, op. cit.

35 Statement of reasons, op. cit.

36 Judgement of the Constitutional Tribunal of 12 April 2000, K 8/98, OTK 2000, No. 3, item 87.

37 Cf. Judgement of the Constitutional Tribunal of 3 November 2004, K 18/03, OTK A/2004, No. 10, item 103; Cf. Wiliński, P., Proces karny $w$ świetle konstytucji, Warszawa 2011, pp. 84-85; Zalasiński, T., Zasada prawidłowej legislacji w poglądach Trybunału Konstytucyjnego, Warszawa 2008, pp. 26-227; Garlicki, L., Polskie prawo konstytucyjne. Zarys wykładu, Warszawa 2009, pp. 60-61; Koksanowicz, G., Zasada określoności przepisów w procesie stanowienia prawa, "Studia Iuridica Lublinensia" 2014, No. 22, pp. 471-478; Bułajewski, S., Zasady prawidłowej legislacji podczas tworzenia aktów prawa miejscowego w Polsce, "Studia Prawnoustrojowe" 2015, No. 29, pp. 31-42.

38 Cf. Wójtowicz, K., Zasada proporcjonalności jako wyznacznik konstytucyjności norm, in: Zubik, M. (ed.), Księga XX-lecia orzecznictwa Trybunału Konstytucyjnego, Warszawa 2006, p. 265 ff.

39 Wiliński, P., op. cit., p. 87; Cf.: Judgement of the Constitutional Tribunal of 12 April 2000, op. cit.; Judgement of the Constitutional Tribunal of 14 June 2000, P 3/00, OTK 2000, No. 5, item 138; Judgement of the Constitutional Tribunal of 25 April 2001, K 13/01, OTK 2001, No. 4, item 81. 
tional right to personal integrity, privacy or inviolability of private premises and the interests of public security and order, it settles disputable issues in compliance with the requirements determined in the Constitution of the RP. ${ }^{40}$

The amended Act also contains provisions that are worthy of approval and have long been awaited. They concern a guarantee of judicial review over the legality of Police operations.

With the existing legislation, the fact that a decision to perform a body check is arbitrarily made by a Police officer is no longer as objectionable as it used to be. This is not about the subjective belief of a Police officer that there are reasonable grounds to suspect that a crime was committed, based on which the officer decides to perform a body check. What is important is that such measures may be reviewed by an independent institution, namely the court. The provisions of Article $15 \mathrm{~d}$ section 11 of the Police Act grant the person subject to a body check the right to verify the legality, validity and accuracy of the body check performed by a Police officer by filing, within 7 days of the date of the check, a complaint with the district court with jurisdiction over the place where the check was performed. If any irregularities are identified in any of these areas, the court is obliged to communicate this fact to the public prosecutor and the chief of a Police unit superior to the unit of the Police officer in question.

The provisions of the Police Act that were repealed by the judgment of the $\mathrm{CT}^{41}$ only granted the person subject to a body check the right to complain against the method of performing the body check to the public prosecutor of venue rather than to the court. Thus, this meant that one law enforcement authority was supposed to review another law enforcement authority, the two authorities usually having converging interests. ${ }^{42}$ In 2008, the CT, in its judgment K 38/07 evaluating the constitutionality of the provisions of Article $236 \$ 2$ of the Code of Criminal Procedure concerning a search, which, due to the personal nature of this measure, are also relevant to a body check, emphasised that "(...) a complaint and the ensuing review do not constitute protection against the arbitrary interference of law enforcement authorities. Its purpose is to minimise the effects, as it is of a consequent nature. The search and confiscation of belongings should be subject to the review of an independent court. Considering the above, due to lack of judicial review over the

40 Skorupka, J., Konstytucyjne i konwencyjne granice przeszukania $w$ postępowaniu karnym (cz.1), "Palestra" 2007, No. 9-10, p. 94.

41 Judgement of the Constitutional Tribunal of 14 December 2017, op. cit.

42 Cf.: Kamińska-Nawrot, A., Kontrola osobista - racjonalność ustawodawcy, "Studia nad Bezpieczeństwem” 2017, No. 2; Kamińska-Nawrot, A., Przeszukanie osoby a kontrola osobista - w kontekście zasady informacji prawnej, "Security, Economy \& Law" 2017, No. 4. 
public prosecutor's decision to search and confiscate belongings and other measures related to the search and confiscation of belongings, this regulation violates the right to trial, because it blocks the judicial manner of protecting constitutional rights and freedoms." 43

\section{Conclusions}

It is beyond any doubt that the amendments obliterated the differences between a body check and the search of a person and significantly extended the authority of Police officers to interfere with the rights and freedoms of an individual.

These provisions are not only disappointing because of their defective structure, the legislator's inconsistency and the lack of regulations governing the conduct of a Police officer during a body check, but, more importantly, they pose a number of threats to an individual and allow for a shocking degree of interference with the constitutional rights and freedoms of an individual. A reasonable suspicion that one is in the possession of items that may be used to commit a criminal offence, even if there is no reasonable suspicion that a criminal offence was actually committed, may be enough for a Police officer to decide that it is duly justified to check private body parts. Moreover, the Police officer may perform the check in any given manner which is not specified by the regulations. This endangers the constitutional rights and freedoms of every individual and is inconsistent with the principles of a democratic state governed by the rule of law.

The above examples show but a few of the problems generated by a body check. The purpose of the expected amendment was mainly to introduce provisions governing the performance of a body check and the search of a person and to specify the limits of public interference with the rights and freedoms of an individual and their rights adequate to the extent to which their personal rights were violated. Unfortunately, the legislator of the Police Act did not satisfy the requirements imposed by the Tribunal and, by removing the line between a body check and the search of a person, transformed the former into an extrajudicial search.

It is indisputable that the Police, whose role is to ensure the safety of people and to maintain public security and order, ${ }^{44}$ should have relevant instruments to deal with those who commit criminal offences. However, the entitlement to perform a body check that interferes with the constitutional rights of an individual as deeply

43 Judgement of the Constitutional Tribunal of 3 July 2008, K 38/07, OTK-A 2008, No. 6, item 102; Starzyński, P., Skutki uznania niekonstytucyjności art. 236 \& 2 k.p.k., "Przegląd Policyjny" 2010, No. 3, pp. 122-131.

Cf.: Pieprzny, S., Policja - organizacja i funkcjonowanie, Kraków 2011. 
as the search of a person contradicts all constitutional standards. There is no doubt that further intervention from the Ombudsman and a subsequent decision of the Constitutional Tribunal are necessary.

\section{References}

Bułajewski, S., Zasady prawidłowej legislacji podczas tworzenia aktów prawa miejscowego w Polsce, "Studia Prawnoustrojowe" 2015, No. 29.

Garlicki, L., Polskie prawo konstytucyjne. Zarys wykładu, Warszawa 2009.

Garlicki, L., Przesłanki ograniczania konstytucyjnych praw i wolności (na tle orzecznictwa Trybunału Konstytucyjnego), "Państwo i Prawo" 2001, vol. 10.

Grochowski, J., Milicyjne przeszukanie pozaprocesowe a konstytucyjne prawa osobiste w PRL, "Problemy Prawa Karnego" 1989, No. 15.

Kamińska-Nawrot, A., Kontrola osobista - racjonalnosc ustawodawcy, "Studia nad Bezpieczeństwem" 2017, No. 2.

Kamińska-Nawrot, A., Przeszukanie osoby a kontrola osobista - w kontekscie zasady informacji prawnej, "Security, Economy \& Law" 2017, No. 4.

Karaźniewicz, J., Przeszukanie i czynności zbliżone do przeszukania w teorii i praktyce organów ścigania, in: Hofmański, P. (ed.), Węzłowe problemy procesu karnego. Materiały konferencyjne - Kraków, 25-28.9.2008, Warszawa 2010.

Kaznowski, A., Karnoprocesowe aspekty przeszukania osoby w polskiej procedurze karnej, "Wojskowy Przegląd Prawniczy" 2008, No. 3.

Koksanowicz, G., Zasada określoności przepisów w procesie stanowienia prawa, "Studia Iuridica Lublinensia" 2014, No. 22.

Łabno, A., Istota zasady proporcjonalności, in: Dukiet-Nagórska, T. (ed.), Zasada proporcjonalności w prawie karnym, Warszawa 2010.

Pieprzny, S., Policja - organizacja i funkcjonowanie, Kraków 2011.

Skorupka, J., Konstytucyjne i konwencyjne granice przeszukania w postępowaniu karnym (cz.1), "Palestra" 2007, No. 9-10.

Starzyński, P., Skutki uznania niekonstytucyjności art. $236 \$ 2$ k.p.k., "Przegląd Policyjny" 2010, No. 3.

Szumiło-Kulczycka, D., Kontrola osobista, przegladanie zawartości bagaży, przeszukanie (przyczynek do kwestii racjonalności legislacji), "Państwo i Prawo" 2012, No. 3.

Tuleja, P. (ed.), Konstytucja Rzeczypospolitej Polskiej. Komentarz, Warszawa 2019.

Wiliński, P., Proces karny w świetle konstytucji, Warszawa 2011.

Wójtowicz, K., Zasada proporcjonalności jako wyznacznik konstytucyjności norm, in: Zubik, M. (ed.), Księga XX-lecia orzecznictwa Trybunału Konstytucyjnego, Warszawa 2006.

Zalasiński, T., Zasada prawidłowej legislacji w poglądach Trybunału Konstytucyjnego, Warszawa 2008. 


\section{CITATION}

KAMIŃSKA-NAWROT, A., Body check or extrajudicial search - chaos in the Police Act, "Acta Iuris Stetinensis" 2020, No. 1 (Vol. 29), 33-47, DOI: 10.18276/ais.2020.29-03. 